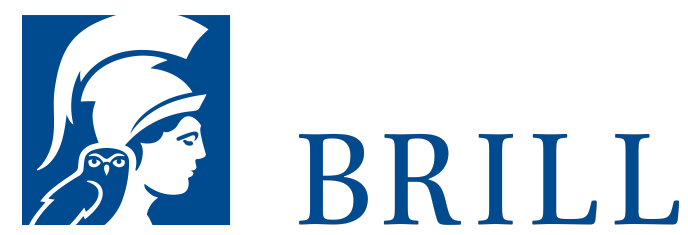

\title{
IV-7 Ordinis quarti tomus septimus
}

Declamativncvla, Isocratis ad Nicoclem Regem de Institvtione Principis, Epistola Consolatoria in Adversis, Oratio de Pace et Discordia, Oratio Fvnebris, Xenophontis Rhetoris Hieron sive Tyrannvs

Authors: Terence Tunberg, Jeroen De Keyser, Edwin Rabbie, Marc van der Poel, and Lucia Gualdo Rosa

This volume of the Erasmi Opera Omnia contains six works in ordo IV, the part on moral issues. The Declamatiuncula, Erasmus' Latin translation of Isocrates' Ad Nicoclem regem de institutione principis, the Epistola consolatoria in adversis, the Oratio de pace et discordia, the Oratio funebris and the translation of Xenophon's Hieron sive tyrannus.

\section{Readership}

All those interested in Erasmus, moral writings, translations, and neo-Latin

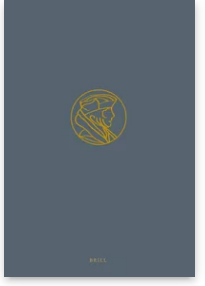

Pages: 25o pp Language: English

Subjects: Early Modern History, History, Intellectual

History, History

Publisher: Brill

Series:

Opera Omnia

Desiderii Erasmi

- Erasmus,

$<$ i $>$ Opera

Omnia</i $>$,

Volume: IV-7

E-Book (PDF)

Released online:

16 Nov 2016

ISBN: 978-90-

04-3289o-7

Hardback

Publication date: 15 Nov 2016

ISBN: 978-90-

04-32889-1

List price

USD \$162.00 
For more information see brill.com

Order information: Order online at brill.com +44330 333 0049 | customerservices@brill.com Submission information: brill.com/authors

Titles published by Brill | Fink, Brill | mentis or Brill | Schöningh: +49(o)715413279216| brill@brocom.de 